\title{
Problems and Their Solutions in a Multicultural Environment According to Pre-service Social Studies Teachers
}

\author{
Sevgi Coşkun Keskin \\ Correspondence: Sevgi Coşkun Keskin, Faculty of Education, Sakarya University, Sakarya, Turkey.
}

Received: May 25, 2018

doi:10.11114/jets.v6i7.3292
Online Published: June 27, 2018

URL: https://doi.org/10.11114/jets.v6i7.3292

\begin{abstract}
Multiculturalism that is a natural consequence of the phenomenon of globalization is a reality that nations cannot ignore nowadays. The social studies course is of special importance at the point of multicultural education. Therefore, there is a need to educate teachers who will teach this lesson consciously and sensitively. This study was conducted to describe problems in a multicultural environment and solution proposals to them based on the discourses of pre-service social studies teachers. The phenomenological approach among qualitative research methods was used in the study. A semi-structured interview form was applied to 110 pre-service social studies teachers. As a result of the coding performed by taking expert opinions, it was determined that the vast majority of the pre-service teachers attributed meanings such as multinational population, the diversity of cultural values, and different races, languages, religions and ethnic structures to multiculturalism. At the point of problems in a multicultural environment, it was observed that they emphasized conflict, social differentiation and division, assimilation, constraints, difficulty of communication and cultural erosion. In the solution of these problems, they suggested regarding differences as wealth and providing education that contains multicultural values.
\end{abstract}

Keywords: multiculturalism, pre-service social studies teachers, problems and their solutions in a multicultural environment

\section{Introduction}

Social scientists tried to explain social, political, cultural and economic changes and transformations in the late $20^{\text {th }}$ century with different concepts. Globalization has undoubtedly become the most popular and widely accepted concept among these concepts (Kızılçelik, 2003). Globalization means the spread of an incident or a meta in many or all parts of the world (Alp \& Kahraman, 2001). Towards the end of the $20^{\text {th }}$ century, many activities such as communication, finance, trade, and sports competitions have gained an international character. Within the scope of these activities, people from different countries come together and exchange goods, services and ideas (Toulmin, 1999).

At the beginning of the $21^{\text {st }}$ century, globalization has become a phenomenon that societies can no longer ignore, and now it is everywhere (Balay, 2004; Kızılçelik, 2003; Yılmaz \& Horzum, 2005). Along with globalization, concepts of the new world order, postmodernism and neo-liberalism are also used. These concepts have close meanings, of which the most popular is undoubtedly globalization (Kızılçelik, 2003). This new period/concept named by some individuals as post-modern and by McLuhan as a "global village" is a reality that affects the lives of all of us, both in a good and bad way, regardless of whether we agree with it or not (Kenan, 2009).

In our globalizing world, a new understanding of politics has emerged on identity. In this new understanding of politics, groups that claim to be different in the society ask for the recognition of their identities in order to preserve and maintain their differences (Başbay \& Bektaş, 2009). The name of this recognition policy is multiculturalism. This concept was born with the adoption of policies that the Australian and Canadian governments, which are two countries that let in immigrants at the beginning of the 1970s, called multiculturalism policies to encourage the cultural diversity of indigenous peoples and immigrants. In the next decade, it spread to English-speaking democratic countries (the United States of America, Great Britain, New Zealand), and then to Europe and Latin America (Doytcheva, 2005). Therefore, multiculturalism reflects a recognition policy that approves the together living of different cultures in a society (Canatan, 2009; Yıldırım, 2002). It is observed that there is diversity in the definitions made for this concept (Fish, 1998; Kymlicka, 1998). The main reason for this diversity is that multiculturalism is a concept that is the subject of many different disciplines from sociology to politics, and from philosophy to education (Ghosh, 2018; Yazıc1, Başol \& Toprak; 2009). 
The APA (2002) defines multiculturalism as the awareness of cultural dimensions such as race, language, sexual preference, religious orientation, education. According to Banks (2009), multiculturalism means becoming aware of race, ethnicity, language, sexual orientation, gender, age, disability, social class, education, religious orientation and other cultural dimensions. According to Erdoğan (1999: 195), multiculturalism is "a political and social system expressing that there is no problem in the together living of different cultural traditions, regardless of their cultural origin, based on the principle of equality." By definition, all societies are multicultural. A society is composed of individuals of different genders, social classes, religions of which practices and sources are different, and who differ by their local and regional qualities due to their origins (Schnapper, 2001). In the simplest terms, multiculturalism is a concept that means cultural diversity, pluralism, and richness (Özensel, 2013).

Multiculturalism has a two-dimensional structure within itself. The first one of these dimensions is to define differences, while the other one is to value differences (Bağlı \& Özensel, 2005). The first dimension refers to a large number of ethnic and cultural groups within the society. Here, these groups are only defined. The other dimension is based not on the composition of the population of different ethnic individuals, but the regulation of the relationship between these individuals (Başbay \& Bektaş, 2009). Considering the present day, in particular, the problems related to the first dimension have almost disappeared. Nearly all countries have accepted their ethnic and cultural diversity. However, it is difficult to say that harmony between these diversities is established in every country. In any case, multiculturalism adopts the conception of preserving and sustaining different cultural values. Nevertheless, criticism and debates about multiculturalism also continue. Bauman (2001) describes multicultural politics as full of noise and anger.

Multiculturalism encompasses different forms of cultural pluralism, each of which presents its own challenge. From past to present, almost all societies have been somehow multicultural. Societies sometimes recognized this cultural diversity, sometimes ignored it, and sometimes tried to standardize it (Barın, 2016). In the process of building a nation-state, one culture was brought to the forefront while other cultures were left aside (Timur, 2001; Üstel, 2011). The biggest problems are encountered in the nation-state structure. While the nation-state builds itself on the ideal of the homogeneity of the nation, its reaction to differences in the society has brought about the strictest practices in the history. This has brought the idea of raising a single type of citizens who have received the same education in the same nation-state process. When considered for the present day, the nation-state project faces a serious challenge. This challenge sometimes referred to as multiculturalism and sometimes as the policy of multiculturalism, emphasizes the phenomenon of diversity that disturbs uniqueness, uniformity, unity, and partnership in the society (Canatan, 2009).

In recent years, it has been observed that the concept of multicultural education plays an important role in studies on education. The concept of multicultural education was introduced at the beginning of the 1970s. In multicultural education, it is aimed that all students have equal opportunity in education without being discriminated by race, ethnic identity, social class or gender (Banks, 2001). Gay (1994) states that the definitions of multicultural education differ and that multicultural education is used in twelve different meanings when the relevant literature is examined. According to Santrock (2001), multicultural education is to be based on different values of cultural groups and to put an emphasis on cultural diversity. According to Banks (2009), multicultural education means the acceptance of differences such as age, sexual preference, social class, ethnicity, religion, language and cultural characteristics and approaching these differences based on love, respect, and tolerance. The aim of this kind of education is to respect students from different religions, races, and with different languages and identities and to enrich the education and training process by transferring these traits to education. Multicultural education is against raising a single type of individual and imposing a single culture. Multicultural education is a system of education in which individuals, who think freely, question, know their own culture, criticize themselves, respect different ideas and ways of life, and consider differences as richness, are raised (Polat \& K1lıç, 2013).

Multicultural education is a completely student-focused system. Since it is student-based education, the aim of multicultural education and the nature of the education to be given may vary from country to country. Each country shapes multicultural education according to its unique historical, sociological and political structure (Açıkalın, 2010; Polat, 2009; Yazıc1, Başol \& Toprak, 2009). The first practices of multicultural education emerged in the USA. The USA started to practise multicultural education by adding a lesson on multiculturalism to programs. Subsequently, multicultural education programs were put into practice in multinational and multicultural countries such as Canada, Australia, Germany and the United Kingdom besides the USA (Güven, 2005).

Turkey has a cultural mosaic in which people from different ethnic origins (Turkish, Kurdish, Arab, Laz, Circassian) live together. Furthermore, languages such as Kurdish, Laz, and Romaic are spoken as a mother tongue, in addition to Turkish, and it is known that the same diversity is also present in relation to religious beliefs. This cultural structure is quite different from other countries (like the USA and Canada). The countries in question have a very rich ethnic, cultural, religious and linguistic diversity due to immigration (Canatan, 2009). When it is considered for Turkey in particular, the reason for diversity is not immigration, it is the elements that have lived together from past to present. 
Özensel (2013) describes this cultural structure/diversity as a rope culture. Thousands of cultures/strings making up the rope are thin, weak and vulnerable on their own. When these cultures/strings come together in the form of ivy, they form a sturdy and strong rope. This sturdy rope itself is the strong cultural structure in Turkey.

When the cultural policies maintained since the declaration of the Republic are examined, it is observed that the nation-state understanding was preserved until recently (Cirrk, 2008; Keskin, 2008; Üstel, 2011). This situation has created an environment that is closed to cultural diversity. The concept of multicultural education, which can be considered as a fairly new concept for Turkey, has not been fully understood. Upon looking at Turkey in the context of multicultural education, it is observed that there are certain problems in this respect. The most significant ones of these problems are the incorrect perception of the society, and the negative effects created by laws and previous practices (Polat \& K1lıç, 2013). Certain researchers even say that our country may be divided and the unitary state structure may be disrupted with multicultural education practices (Cirrk, 2008).

In Turkey, a significant part of the knowledge, skills, and values related to social life is attempted to be given to students through the Social Studies course (Öztürk, 2006; Safran, 2008). One of the most important aims of this course, which is considered as a tool in citizenship education, is to raise active citizens who have adopted multicultural understanding (Danker, 2003; Öztürk \& Deveci, 2011; Welton \& Mallon, 1999). Therefore, the social studies course has special importance at the point of multicultural education. In certain previous studies (Açıalın, 2010; Aslan, 2017; Arslan, 2016; Cırık, 2008; Ertürk, 2006; Keskin, 2008; Keskin \& Yaman, 2014; Polat, 2009; Şimşek, 2007), it was determined that multicultural education is emphasised in the curriculum and course books of the Social Studies course, published in 2005 in Turkey. Based on this, it can be said that multicultural education has been started in Turkey especially in social studies lessons as of 2005.

Faculties of education that are institutions raising teachers in Turkey were established in 1992 (Öztürk, 1999; Akyüz, 2012). The department of social studies teaching established within the faculties of education in 1997 admitted students that year for the first time. Immediately after the report entitled "Rearrangement of Teacher Training Programs of Education Faculties" published by the YÖK (Council of Higher Education) in 1998, the social studies teaching program was also renewed together with other teaching areas (YÖK, 1998). These renewed programs have continued to be used in faculties of education to this day. As mentioned above, the transition to multicultural education was realized in the social studies program published in 2005. In parallel to this change, there has been no change in the faculty of education social studies teaching program. Upon examining the undergraduate program in this field, it is clear observed that there is no lesson for multicultural education (Polat \& K1liç, 2013; Y1lmaz, 2016). Furthermore, it was determined in previous studies conducted on both teachers and pre-service teachers in Turkey that there are deficiencies and mistakes both in terms of the perception and implementation of the concept of multicultural education in common (Demircioğlu \& Özdemir, 2014).

As explained above, the social studies course is very important for multicultural education, and the transition to multicultural education was realized with the 2005 curriculum of this course. For this reason, it is important to determine the opinions of pre-service teachers who will teach this lesson on problems in the multicultural educational environment. The answers to the following questions were sought in the study:

1. What are the meanings attributed by pre-service social studies teachers to the concept of multiculturalism?

2. What are the problems in a multicultural environment according to pre-service social studies teachers?

3. What are the suggestions of pre-service social studies teachers for solving the problems in a multicultural environment?

\section{Method}

This study was conducted with the phenomenological approach among qualitative research methods. Phenomenology aims to provide an in-depth understanding of the meaning or nature of our everyday experiences (Patton, 2014). It is to try to understand the individual meaning-structures (opinions and views) and intentions of individuals from their point-of-view. Therefore, phenomenology generally directs to the inner world and consciousness structures of individuals in human sciences. The main purpose of the analysis is to grasp the existence and the essence of things. As a phenomenon in this study, the opinions of pre-service social studies teachers who will compare individuals with the multiculturalism phenomenon were determined on problems and solution proposals to them in a multicultural environment.

\subsection{Participant Group}

Easily accessible case sampling among purposeful sampling methods was used in the study. 110 pre-service social studies teachers studying at a university in Turkey participated in the study on a voluntary basis. 61 of the participants are female, and 49 are male. 


\subsection{Data Collection Tool, Process, and Analysis}

The data collection and analysis process consisted of seven stages, namely, the preparation for creating interview questions, preparation of a semi-structured interview form, data collection, data review, data coding, data theming, and reporting. At the first stage, three pre-service teachers were interviewed about multiculturalism in order to prepare the data collection tool, and these were recorded. At the second stage, the main questions to be asked were selected from the interview analyzed, and a semi-structured interview form was created. In the data collection process, which is the third stage, the volunteer pre-service teachers were given a form, and it was ensured that they answered the questions in the form in approximately 60 minutes. Then, general codes were provided by reviewing the data and interview forms a few times, and the codes that are in a close framework to each other were themed. In this context, the ways of content analysis were followed when analyzing the data because themes/categories were achieved from the codes obtained in accordance with the research questions (Yıldırım \& Şimşek, 2011).

\subsection{Validity and Reliability}

To ensure the internal validity of the study, expert opinions were taken in coding and theming. Purposeful sampling was used for external validity. Furthermore, examples of the themes are given in the findings by sticking to the original, in accordance with the detailed description principle. The personal information of the pre-service teachers was not taken while the data were collected to ensure reliability. Therefore, it was attempted to make them give more sincere answers.

\section{Results}

The findings obtained from the interview form applied to pre-service teachers are presented below under three headings in accordance with the research questions. The first heading includes meanings attributed to the concept of multiculturalism by pre-service teachers, the second heading includes their opinions on the problems in the multicultural environment, and the last heading includes their suggestions for the solution of these problems.

\subsection{Multiculturalism According to Pre-service Social Studies Teachers}

Below is the graph of the themes achieved as a result of the analysis of the discourses of pre-service teachers on multiculturalism.

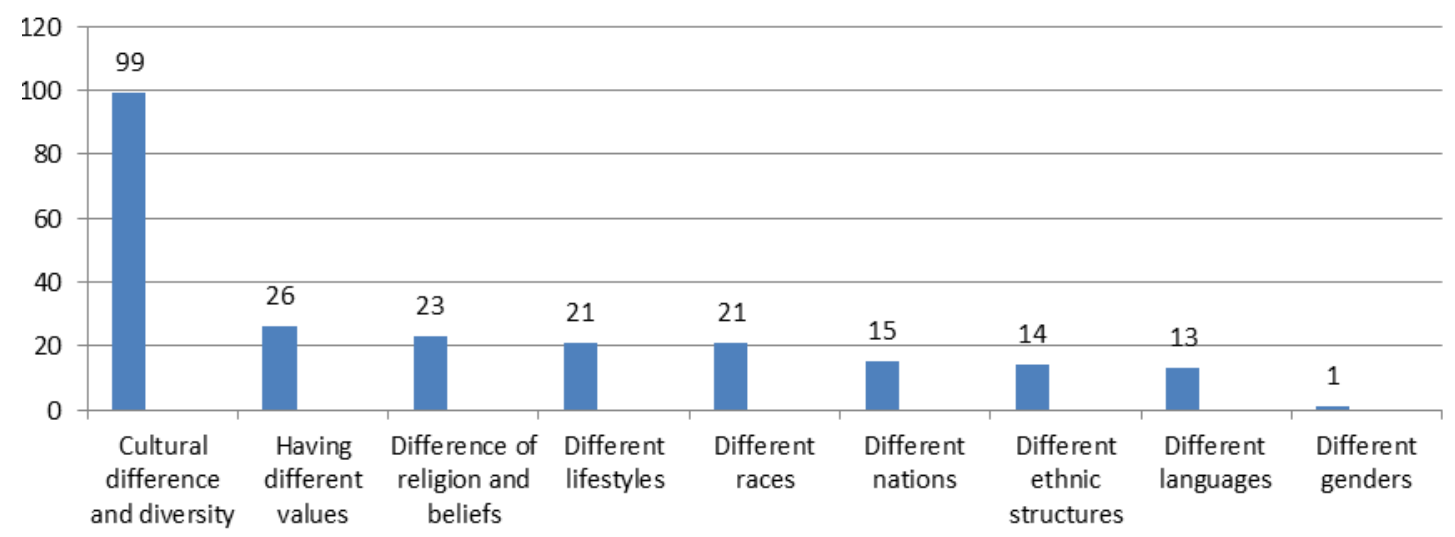

Graph 1. Meanings attributed to the concept of multiculturalism according to pre-service social studies teachers

Upon examining Graph 1, it is observed that pre-service social studies teachers attribute meanings such as cultural differences and diversity $(99,90 \%)$, having different values $(26,24 \%)$, differences of belief and religion (23, 21\%), different lifestyles $(21,19 \%)$, different races $(21,19 \%)$, different nations $(15,14 \%)$, different ethnic structures (14, $13 \%)$, different languages $(13,12 \%)$, different genders $(1,1 \%)$ to the concept of multiculturalism. When these meanings that teachers attribute to the concept of multiculturalism are examined collectively, it is clearly observed that the focus is on the concept of "difference/being different". The codes/student discourses and frequencies that ensure the access to the themes given are shown in Graph 1 (Table 1). 
Table 1. Multiculturalism codes and themes according to pre-service social studies teachers

\begin{tabular}{|c|c|c|c|}
\hline Codes & $\mathbf{N}$ & $\sum \mathbf{N}$ & Themes \\
\hline The diversity of cultural values & 55 & \multirow{6}{*}{99} & \multirow{6}{*}{ Cultural difference and diversity } \\
\hline The existence / co-living of individuals from different cultures & 25 & & \\
\hline Different traditions and customs & 11 & & \\
\hline Family culture & 5 & & \\
\hline A multicultural society is like a garden with flowers & 2 & & \\
\hline Meeting different cultures with migration movements & 1 & & \\
\hline The presence of different values is richness & 20 & \multirow{2}{*}{26} & \multirow{2}{*}{ Having different values } \\
\hline Each society has its own value judgment & 6 & & \\
\hline Religious difference & 21 & & \\
\hline Freedom of belief & 2 & 23 & Ditrerences or religion and beliers \\
\hline Different lifestyles & 10 & \multirow{6}{*}{21} & \multirow{6}{*}{ Different lifestyles } \\
\hline Richness, abundance in a society & 5 & & \\
\hline Different economic levels & 2 & & \\
\hline Clothing style & 2 & & \\
\hline Difference of mentality & 1 & & \\
\hline Difference of the geography where people live & 1 & & \\
\hline Race discrimination & 21 & 21 & Different races \\
\hline Multi-national state & 10 & \multirow{2}{*}{15} & \multirow{2}{*}{ Different nations } \\
\hline Different historical development/process & 5 & & \\
\hline Different ethnic structure & 14 & 14 & Different ethnic structures \\
\hline Different languages & 13 & 13 & Different languages \\
\hline Different genders & 1 & 1 & Different genders \\
\hline
\end{tabular}

As can be seen in Table 1, it can be said that almost all the pre-service teachers $(99,90 \%)$ perceive multiculturalism as cultural differences and diversity. The discourses of the students who emphasized this theme are presented below.

K1: It is quite normal for each society to have a value judgment because the geography where people live and their socio-economic situations affect their character and thoughts. If you lie down with dogs, you will rise up with fleas. Being multicultural and having many value judgments in the society are richness in the name of humanity. Let us imagine that there is a value, a tradition that is valid for the whole humanity. How terrible the world would be. Always the same understanding, the same thought. Everyone would seem to be out of the same factory. (Cultural difference and diversity/Having different values).

K9: A multicultural society is like a garden with flowers. While a garden with flowers reminds us of flowers of different colours and types, so are multicultural societies. Each culture represents a flower. It is more attractive, it is always more colourful. (Cultural difference and diversity)

E28: Even the best painter of the world cannot express anything with a single colour. If he uses the white colour only, it will be nothing better than leaving meaningless shapes on the paper. The more colours are, the stronger the power of expression is. Societies also become more colourful and attractive when they are multicultural. Furthermore, different social colours are together in many fields. From food to clothes. (Cultural difference and diversity)

On the other hand, while having different values $(26,24 \%)$, different religions and beliefs $(23,21 \%)$, different lifestyles $(21,19 \%)$, different races $(21,19 \%)$ are expressed approximately by one fifth of the study group, different nations (15, $14 \%)$, different ethnic structure $(14,13 \%)$ and different religions $(13,12 \%)$ were expressed approximately by one-tenth. Different gender was expressed by only one individual. No emphasis was made on different socioeconomic classes. Examples related to the subject are as follows.

K9: A multicultural society is like a garden with flowers. While a garden with flowers reminds us of flowers of different colours and types, so are multicultural societies. Each culture represents a flower. It is more attractive, it is always more colourful. (Having different values)

K12: As in our country, multicultural societies have many differences from their lifestyles, understanding of respect, morality, honour, and meanings attributed to days, to beliefs. (Different lifestyles)

E14: Our country has a multicultural structure. It includes people from different ethnic backgrounds such as Armenian, Jewish, Assyrian, etc. People from different ethnic backgrounds in our country can comfortably worship, maintain their education, and maintain their lives in social and economic life without difficulty. (Different ethnic structures/different beliefs)

\subsection{Problems in the Multicultural Environment According to Pre-service Social Studies Teachers}

According to pre-service social studies teachers, problems in the multicultural environment are mainly conflict (74, $67 \%)$, the presence of variations and divisions that disrupt the social order (72, 65\%), effort of not being assimilated/assimilating $(57,52 \%)$ formation of restrictions $(24,22 \%)$, difficulty of communication $(17,15 \%)$ and 
cultural erosion $(13,12 \%)$. The graph that shows the themes is presented below.

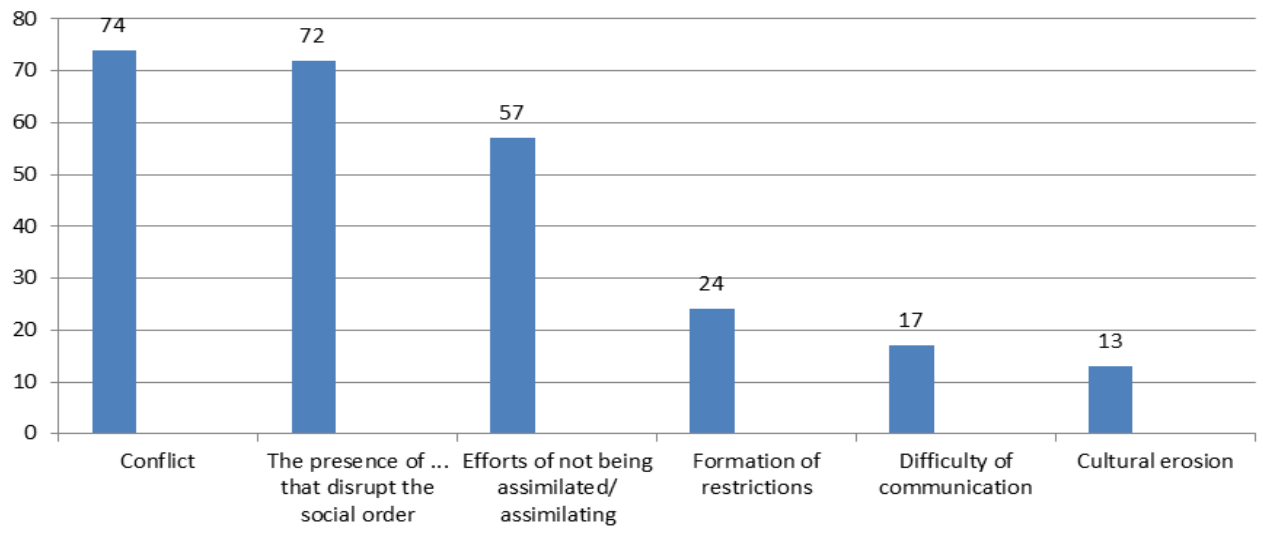

Graph 2. Problems in the multicultural environment according to pre-service social studies teachers

Upon examining the graph above, it is observed that more than half of the pre-service teachers focus on the problems of conflict, marginalization that disrupts the social order and assimilation. The student discourses that ensure the achievement of these themes and their frequencies are given in the table below (Table 2).

Table 2. The codes and themes of the problems in the multicultural environment according to pre-service social studies teachers

\begin{tabular}{|c|c|c|c|}
\hline Codes & $\mathbf{N}$ & $\sum \mathbf{N}$ & Themes \\
\hline Conflicts and contradictions & 25 & \multirow{8}{*}{74} & \multirow{8}{*}{ Conflict } \\
\hline Clash/difference of religion and beliefs & 20 & & \\
\hline Intolerance/disrespect towards people with different values & 11 & & \\
\hline Chaos & 7 & & \\
\hline Misunderstanding & 5 & & \\
\hline Value conflict & 4 & & \\
\hline Cultural conflict & 1 & & \\
\hline Unconsciously attacking the state & 1 & & \\
\hline Having different values & 22 & \multirow{6}{*}{72} & \multirow{6}{*}{$\begin{array}{c}\text { The presence of marginalization and divisions } \\
\text { that disrupt the social order }\end{array}$} \\
\hline Different lifestyles & 21 & & \\
\hline Marginalization/Exclusion & 11 & & \\
\hline Different language, historical and cultural problems & 9 & & \\
\hline Different ways of thinking & 6 & & \\
\hline Division of the society/grouping & 3 & & \\
\hline The efforts of cultures to protect their self & 17 & \multirow{7}{*}{57} & \multirow{7}{*}{ Not being assimilated/ assimilation effort } \\
\hline Cultural corruption & 11 & & \\
\hline The idea that everybody should think like oneself & 9 & & \\
\hline Efforts of communities to spread their own religion and thought & 8 & & \\
\hline Being assimilated & 6 & & \\
\hline The fact that every nation wants to live their own culture & 3 & & \\
\hline The fact that the top society assimilates the values of the sub-society & 3 & & \\
\hline Not being able to practise one's religion & 10 & \multirow{3}{*}{24} & \multirow{3}{*}{ Formation of restrictions } \\
\hline Not being able to talk in one's native language & 10 & & \\
\hline Human rights violations & 4 & & \\
\hline Having prejudices & 9 & \multirow{6}{*}{17} & \multirow{6}{*}{ Difficulty of communication } \\
\hline The fact that one group thinks itself superior & 3 & & \\
\hline End of tolerance & 2 & & \\
\hline Having communication problems & 1 & & \\
\hline Not being able to empathize & 1 & & \\
\hline The fact that people assess other people according to their own culture & 1 & & \\
\hline The decline in respect towards the elderly and love towards children & 5 & \multirow{5}{*}{13} & \multirow{5}{*}{ Cultural erosion } \\
\hline The weakening of family ties & 3 & & \\
\hline Changes of the outfit & 3 & & \\
\hline Corruption of values by the media & 1 & & \\
\hline Loss of cultural features & 1 & & \\
\hline
\end{tabular}


M17: One of the most important causes of value conflicts in a multicultural society is that people want to see everybody as themselves. People have called those who are not like themselves "the other" throughout the history. They thought that the other should exist for them to exist and aimed to assimilate the people in the opposite party each time. This situation is valid for the other party, as well as me. Anatolia, where we live nowadays, hosted countless "other" people throughout the history. Me and we have emerged today, with the integration and interaction of these "other" people. Cultural differences have always been a problem in our society because we always evaluate the "other" people living in our society according to our own truths and cultural structure. (Conflict/ The effort of not being assimilated/ the effort to assimilate/ the presence of marginalization and divisions that disrupt the social order)

M21: There is no problem if these cultures can integrate and become mottled. Nevertheless, there is a problem if they are a mosaic. Not every culture can embrace one another. (Conflict)

M28: ... the difference in values stands out at most. What is good for you may conflict with what is good for someone else. What is right for you may be wrong for someone else. Then, we hear voices like this from the people around: "I think this is wrong, what is right can be...", "But are you a criterion? Who selected you as a spokesperson?" It is quite difficult to meet in a common understanding with this intolerance. Especially in this geography, such discourses cause suffering, and an ember burns where it falls. Whereas the fire should have burnt us, wherever it fell. A gun should have shot us before getting out of the barrel. We should have stepped in the fire without waiting for the firemen. The idea that someone will put out the fire makes it nothing better than kindling it more. (Conflict)

M42: Probably, the most significant value problem in multicultural societies is the difference in the lifestyle, thoughts, views on life of each culture because each culture has its own way of thinking and point-of-view. (The presence of marginalization and divisions that disrupt the social order)

Other themes related to the problems that may be present in a multicultural environment are the effort of not being assimilated/assimilating $(57,52 \%)$, formation of restrictions $(24,22 \%)$, difficulty of communication $(17,15 \%)$ and cultural erosion $(13,12 \%)$. The examples of the themes are as follows:

F2: The most important value problems in a multicultural society structure are that people cannot practise their religion openly and some nations cannot use their mother tongues. (Formation of restrictions)

F18: It is really difficult to live under a different cultural identity in a society. One of the problems here is that we cannot get rid of our prejudices. Let alone believing in and adopting only our own truths and acting accordingly, we also impose what we know wrong on other people and make them take a stand as well. (Difficulty of communication)

M58: We see that values such as respect and attachment to the family, sincerity in personal relations, friendship relations, etc., which are the most important values in a society with the high level of culture, are problematic. (Cultural erosion)

\subsection{Solution of the Problems in a Multicultural Environment According to Pre-service Social Studies Teachers}

According to pre-service social studies teachers, solutions to the problems in a multicultural environment are mainly aimed at the following themes: the values that must exist in a multicultural society should be introduced (104, 95\%), training should be provided $(103,94 \%)$, differences should be accepted $(21,19 \%)$, the state should take measures in relation to the subject $(20,18 \%)$. The graph showing these themes is as follows.

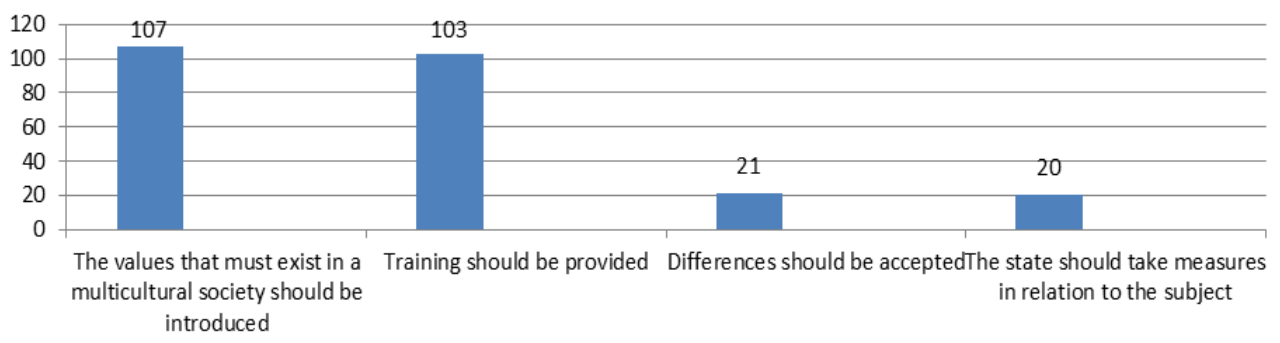

Graph 3. Ways of solving the problems in a multicultural environment according to pre-service social studies teachers

Upon examining graph 3, it is stated that almost all the pre-service teachers want that the necessary values aimed at solving the problems that are present in a multicultural environment should be introduced and training should be provided for this purpose. The student discourses that ensure achieving these themes and their frequencies are presented in the table below (Table 3). 
Table 3. Codes and themes for the solution of the problems in a multicultural environment according to pre-service social studies teachers

\begin{tabular}{|c|c|c|c|}
\hline Code & $\mathbf{N}$ & $\sum \mathbf{N}$ & Themes \\
\hline We should respect people and different cultures & 43 & \multirow{5}{*}{104} & \multirow{5}{*}{$\begin{array}{l}\text { The values that must be present in a } \\
\text { multicultural society should be } \\
\text { introduced }\end{array}$} \\
\hline Tolerance (Tolerance towards different religions and races should be taught) & 29 & & \\
\hline We should love people/instil love & 18 & & \\
\hline We should instil love to break the prejudices. & 8 & & \\
\hline We should act in unity and solidarity. & 6 & & \\
\hline Training should be provided & 48 & \multirow{9}{*}{103} & \multirow{9}{*}{ Training should be provided } \\
\hline Children should be taught the values & 27 & & \\
\hline Love for human beings (humanism) should be taught & 7 & & \\
\hline Family education should be provided /education should be provided at home & 7 & & \\
\hline The concept of culture should be taught to students & 5 & & \\
\hline Case study method should be used & 3 & & \\
\hline Citizenship training should be provided & 2 & & \\
\hline Looking after and protecting the territories where one lives should be taught & 2 & & \\
\hline The social studies course should be used as a tool & 2 & & \\
\hline Considering differences as richness & 18 & \multirow{4}{*}{21} & \multirow{4}{*}{ Differences should be accepted } \\
\hline We should be humanist & 1 & & \\
\hline Being tolerant & 1 & & \\
\hline Making others become aware of similarities & 1 & & \\
\hline Everyone should be treated in an equal and fair manner & 7 & \multirow{7}{*}{20} & \multirow{7}{*}{$\begin{array}{l}\text { The state should take measures in relation } \\
\text { to the subject }\end{array}$} \\
\hline The state should respect the human rights & 4 & & \\
\hline Awareness should be raised & 4 & & \\
\hline The practices should not remain on paper, they should be implemented & 2 & & \\
\hline Strict laws should be made & 1 & & \\
\hline Outbursts and provocations should not be allowed & 1 & & \\
\hline The problems should not be reflected on the public opinion by exaggerating & 1 & & \\
\hline
\end{tabular}

F5: Let's think like this; just as we also see on the media, an animal with offsprings may act as the mother of an abandoned or lost offspring, by not discriminating it from the others. This means that maybe a baby has turned back to life. Maybe, that offspring will grow up and protect the family better. Let's think and speculate as countries; the more tolerance towards the diversity in the society is, the more citizens are gained. A student who has come to the class from the outside can be given as an example when it is intended to make this subject understood. The more we adopt and do not exclude that student, the more success of that student will spread to the class first, then to school, other schools and maybe to the country. And this makes that person really proud. The success of winning that person and subsequent success also flatter our pride. (The values that must exist in a multicultural society should be introduced)

M5: It is necessary to develop an education system that protects the structure of our society, embraces our values, religion and our national integrity, and does not consider them as something frightening. These act as the cement that keeps a nation alive (so to speak). (Training should be provided)

M8: We must raise individuals who think in a humanist way like Mevlana, try to understand and question, but do not conflict with the elements that they do not understand as long as their constitutional freedoms are not restrained. We should teach them the "ahidname" of Fatih Sultan Mehmet. We should explain and show the games played by those who have showed individuals with the sense of a single peaceful homeland under the same flag for hundreds of years and tried to set us against each other with a realistic initiative with current events. We should teach that there are people trying to create chaos over values such as religion, homeland and language by using our social sensitivities. We should teach people that religion and patriotism are both based on respecting and tolerating the differences, by introducing the awareness of religion, language and homeland. We should make students understand that they actually say the same things in different languages or make them understand what they read from different religious books. Above all, the process that is started by giving them well-equipped teachers and teaching them peace and being tolerant are very easy with the right methods in today's world where even children are killed cruelly (The values that must exist in a multicultural society should be introduced/Training should be provided)

M31: In order to overcome these value problems, the training to be given to individuals is based on the fundamental principle of "freedom in love, compulsion in respect". So, it is a virtue to show respect for those 
we do not like, as well. The more individuals we raise based on this principle, the further we go. The second important point is to establish the conception of "Our diversity is our richness". We must teach people that the differences of societies are a unifying element rather than a cause of dissociation and grouping. We must exemplify our ancestors in this regard. (The values that must exist in a multicultural society should be introduced/ Training should be provided)

M13: We can solve the problems when we have our people take off their blinkers. Another obstacle is the prejudice of our people. When these prejudices break down, then unity and solidarity will be ensured. In this regard, our educators have a great responsibility. We should remove the blinkers in our children's eyes and show them the facts. (The values that must exist in a multicultural society should be introduced)

The themes that the differences of the pre-service teachers should be accepted $(21,19 \%)$ and the state should take measures $(20,18 \%)$ are supported by approximately one fifth of the group. The examples on these themes are as follows:

F9: Students should be taught what a multicultural structure is like and its importance. They should realize different values and understand their importance starting from the classroom environment. We should make children adopt the idea that there is actually no big problem and each individual has his/her own values and rights. We must have them realize that disrespect towards values is a problem, rather than the diversity of values. We should raise awareness of living in a respectful manner to each sub-culture peacefully in a multicultural environment. ... We can also have them understand that each society has a multi-cultural structure, but not every society can live in peace. (Differences should be accepted)

M20: Here, the state has many duties. If we are investing in the cultural structure, we must invest equal amounts in material and moral structures, as well. There should not be practices that would cause differences to emerge. It is also possible to make educators grasp something by sending them to different places, i.e. different cultures. We should remember that, at the last stop, no one will be discriminated. (The state should take measures in relation to the subject)

M17: When a problem arises, there is only one reason. That is ignorance and disrespect. It is necessary to teach people to accept at this point where human pride comes to the forefront. At this point, education to be given to people is very important. The Alevi-Sunni issue, which causes conflicts in our society today, can be eliminated by teaching the religious culture and moral knowledge lesson at the primary and secondary levels of elementary education in a strict manner, having students comprehend all aspects of all religions and beliefs, and setting individuals free in this respect. (Differences should be accepted/ The state should take measures in relation to the subject)

\section{Discussion}

Multiculturalism, which is a very important phenomenon when considering for the present day, shows its effect all over the world. Each state develops and implements multicultural policies, more or less. These policies are reflected in education and training programs that are prepared and an effort is made to make school children adopt them. The concept that emerges at this point is multicultural education. In multicultural education, the aim is to raise individuals who think freely, question, respect different ideas and ways of life, and who know that differences are richness.

Certain courses seem important for multicultural education. One of these courses is undoubtedly social studies (Welton \& Mallon, 1999). Specifically, for Turkey, transition to multicultural education was realized in the social studies curriculum prepared in 2005 (Ertürk, 2006; Keskin 2008; Keskin \& Yaman, 2014). At this point, it is important to raise awareness among teachers who will teach this lesson of multiculturalism and multicultural education. However, it is observed that there is no such lesson upon examining the undergraduate programs in which social studies teachers are raised (Polat \& K1lıç, 2013). This study was conducted in order to reveal the point-of-views of pre-service social studies teachers, who are very important for multicultural education and who will give the social studies lesson, on the concept of multiculturalism and problems in a multicultural environment, and solution to them.

In the study, first of all, it was attempted to determine the meanings attributed by pre-service social studies teachers to the concept of multiculturalism. $90 \%$ (99 individuals) of the pre-service teachers in the study group describe this concept as "cultural difference and diversity". It is also observed that they attribute different meanings to the concept of multiculturalism such as having different values, differences in religion and belief, different lifestyles, different races, different nations, different ethnic structures, different languages, and different genders. When the meanings that teachers attribute to the concept of multiculturalism were examined collectively, it was determined that the common point was the emphasis on "difference/being different". Upon examining the multiculturalism definitions in the introduction section of the study (APA, 2002; Banks, 2009; Schnapper, 2001; Özensel, 2013), it is observed that all definitions emphasize difference/being different. Banks (2009) stated that there are differences of language, religion, race, age, gender, economic level, social class and disability among students in 
multicultural education. At this point, the meanings attributed by pre-service social studies teachers to the concept of multiculturalism are quite accurate. Coşkun (2012) determined that pre-service religious culture and moral knowledge teachers have positive attitudes and thoughts in relation to multiculturalism, while Demir and Başarır (2013) determined the same for pre-service teachers studying in seven different fields (Religious culture and moral knowledge, social studies, science, etc.), and Polat (2009) and Yllmaz (2016) determined the same for pre-service teachers studying in different fields. Furthermore, similar results were obtained in studies (Aslan, 2017; Yazıcı, Başol \& Toprak, 2009) conducted on teachers. On the other hand, the fact that gender differences are not adequately expressed in the context of multiculturalism shows inadequacy in this respect. Therefore, pre-service teachers should be introduced with the emphasis that gender difference is one of the types that enrich the society.

Secondly, pre-service social studies teachers were asked to describe problems in the multicultural environment in the study. Approximately one third of the pre-service teachers described the problems gathered under the themes of "conflict" (67\%) and "the presence of marginalization and divisions that disrupt the social order" (65\%) Under these two themes, they expressed that there are/may be conflicts originating mainly from religion, language, belief, different lifestyles, differences in value and culture. It is interesting that pre-service teachers express the meanings attributed to the concept of multiculturalism as problems in the multicultural environment once again. Nowadays, just as all around the world, one of the main problems in Turkey is "how to achieve unity within differences" (Arslan, 2016). Indeed, the basic problem in a multicultural environment is how to ensure harmony in an environment with differences. Other problems expressed by pre-service teachers were gathered under the theme of the effort of not being assimilated/assimilating (52\%), formation of restrictions (22\%), difficulty of communication (15\%) and cultural erosion (12\%). Multiculturalism has its own two-dimensional structure, as mentioned in the introduction section of the study. The first one of these dimensions is to define differences, and the other one is to value differences (Bağlı \& Özensel, 2005). Specifically, for today, the problems related to the first dimension are almost eliminated. Almost all countries have accepted their ethnical and cultural diversity. Nevertheless, it is hard to say that harmony has been established in this diversity in all countries. In their study, Başbay and Bektaş (2009) argue that multiculturalism is an important factor in ensuring integration, not disintegration, and that differences create the cultural richness. On the other hand, there are those who argue the exact opposite. In a study conducted on the Turks living in Germany, Ceylan (2016) clearly showed that the German government follows an assimilation policy against foreigners. Furthermore, Bauman (2001) describes multicultural politics as full of noise and anger. In societies where more than one culture coexists, people can start to judge each other according to their own values and beliefs after some point, which can cause great pressure especially on minority groups, as well as conflict and separation between sub-cultures. Therefore, it can be said that pre-service teachers indicate the problems that may occur in the multicultural environment rather than those that have already happened.

Finally, in the study, pre-service social studies teachers were asked to make suggestions for solving problems in a multicultural environment. Almost all of the study group proposed solutions to problems in a multicultural environment under the themes of "the values that must exist in a multicultural society should be introduced" (95\%), and "training should be provided" (94\%). Therefore, it can be said that multicultural education is considered as a very important tool in the values education. Indeed, Banks (2009) pointed out the importance of multicultural education in introducing values to children in his study. In studies conducted on students receiving multicultural education (Gay, 1994; Hollins, 1996; Ware, 2006), it was determined that there is an increase in the academic achievement of students in common. In his study, Aslan (2017) found out that teachers use the case study method in multicultural education based on the activity. In this study, some of the pre-service teachers suggested this method under the theme of "training should be provided". The secret of success in a multicultural environment is destroying the prejudices of individuals to one another (Banks, 2009, Dunn, 1997). This is possible by raising awareness among children through multicultural education. Other solution proposals of the pre-service teachers were gathered under the themes of "differences should be accepted" (19\%) and "the state should take measures" (18\%).

The success of multicultural policies and multicultural education largely depends on the education of teachers. In this study conducted with pre-service social studies teachers, very positive results were achieved although they did not receive any course related to this subject in the undergraduate program. The meanings attributed by pre-service teachers to the concept of multiculturalism, the problems they determined and their suggestions for the solution of the problems are largely similar to those who are trained on this subject. Nevertheless, it is also obvious that there are certain deficiencies. At this point, a teacher training model that is based on multicultural education is required in Turkey. Indeed, Polat and Kılıç (2013), Arslan (2016) and Aslan (2017) made the same suggestion.

\section{References}

Açıkalın, M. (2010). New approaches in social studies education: Multicultural and global education. İlkögrretim Online, 9(3), 1226-1237. 
Akyüz, Y. (2012). History of Turkish Education. 22. Bask1. Pegem Akademi: Ankara

Alp, A., \& Kahraman, A. (2001). Globalization and policy convergence. Downloaded from http://www.libra-dt.org.tr/guncel/Diger/alp_kuresellesme.htm on 15 September 2009

APA (2002). Guidelines on multicultural education, training, research, practice, and organizational change for psychologists. Quoted from http://www.apa.org/pi/multiculturalguidelines/homepage.html on October 7, 2006.

Arslan, S. (2016). Multicultural education and Turkey: present situation, expectations, possibilities. Elektronik Sosyal Bilimler Dergisi, 15(57), 412-428.

Aslan, S. (2017). Examination of social studies teachers' opinions on multicultural education. Ahi Evran Üniversitesi Kırşehir Eğitim Fakültesi Dergisi, 18(2), 231-253.

Bağl1, M., \& Özensel, E. (2005). Multicultural citizenship. Konya: Çizgi Kitapevi.

Balay, R. (2004). Globalization, information society and education. Ankara University Journal of Faculty of Educational Sciences, 37(2), 61-82.

Banks, J. A. (2001). Multicultural education: Goals, possibilities and challenges. In C. F. Diaz (Ed.), Multicultural education in the 21st century (pp. 11-22). New York, NY: Addison-Wesley. https://doi.org/10.1016/B0-08-043076-7/02390-1

Banks, J. A. (2009). Multicultural education: Characteristics and goals. Banks J. A. \& Banks. C. A. M. (Eds) Multicultural Education Issues and Perspectives (p. 3-32). Seventh Edition. USA: John Wiley \& Sons, Inc.

Barın, T. (2016). A liberal approach to living together: Multiculturalism theory. Ylldırım Beyazıd Hukuk Dergisi, 2, 57-88.

Başbay, A., \& Bektaş, Y. (2009). Instructional environment and teacher competences in the context of multiculturalism. Education and Science, 34(152), 30-43.

Bauman, Z. (2001). Identity in the globalising world. Social Anthropology, 9(2), 121-129. https://doi.org/10.1111/j.1469-8676.2001.tb00141.x

Canatan, K. (2009). Multiculturalism in European societies: A sociological approach. Uluslararası Sosyal Araştırmalar Dergisi, 2(6), 80-96.

Ceylan, Y. (2016). European Multiculturalism Models (Germany Sample). The Journal of International Social Research, 9(43), 1207-1215. https://doi.org/10.17719/jisr.20164317688

Cırık, İ. (2008). Multicultural education and its reflections. Hacettepe Üniversitesi Eğitim Fakültesi Dergisi, 34, 27-40.

Coşkun, M. K. (2012). Attitudes of religious culture and moral knowledge pre-service teachers towards multicultural education. Dumlupinar Üniversitesi Sosyal Bilimler Dergisi, 34, 33-44.

Danker, A. C. (2003). Multicultural social studies: Using local history in the classroom. New York, US: Teachers College Press.

Demir, S., \& Başarır, F. (2013). Examination of self-efficacy perceptions of pre-service teachers in the context of multicultural education. International Journal of Social Science, 6(1), 609-641

Demircioğlu, E., \& Özdemir, M. (2014). Examination of pedagogical formation students' attitudes towards multicultural education according to certain variables. Ege Eğitim Dergisi, 15(1), 211-232. https://doi.org/10.12984/eed.22924

Doytcheva, M. (2005). Le multiculturalisme. Paris: La Découverte, coll.

Dunn, R. (1997). The goals and track record of multicultural education. Education Leadership, 54(7), 74-77.

Erdoğan, M. (1999). Liberal society, liberal politics. Ankara: Siyasal Kitabevi.

Ertürk, E. (2006). Transformation of the understanding of society, citizenship, patriotism and economy in course books: a content analysis on 1997 and 2004 primary school social studies course books. Yayınlanmamış yüksek lisans tezi, Mimar Sinan Güzel Sanatlar Üniversitesi, Sosyal Bilimler Enstitüsü, İstanbul.

Fish, S. (1998). Boutique multiculturalism. in A. Melzer, J. Weinberger and M. R. Zinman (eds), Multiculturalism and American Democracy, pp. 69-88. Lawrence: University Press of Kansas.

Gay, G. (1994). A synthesis of scholarship in multicultural education. Urban Monograph Series. Quoted from https://files.eric.ed.gov/fulltext/ED378287.pdf on November 10, 2017

Ghosh, R. (2018). Multiculturalism in a comparative perspective: Australia, Canada and India. Canadian Ethnic Studies, 50(1), 15-36. https://doi.org/10.1353/ces.2018.0002

Güven, E. D. (2005). Repeated criticism on education, alternative suggestions. PIVOLKA, 4(17), 6-8. 
Hollins, E. R. (1996). Culture in school learning: Revealing the deep meaning. Mahwah, NJ: Erlbaum.

Kenan, S. (2009). What is the primary goal of education in the globalizing world? Educational Philosophy Conferences In an ethical overview of education in the globalizing world (p. 47-53). İstanbul: Bahçeşehir Üniversitesi.

Keskin, Y. (2008). Values education in social studies curricula in Turkey: Historical development, investigation of the effectiveness of the 1998 and 2004 curricula. Yayınlanmamış doktora tezi, Marmara Üniversitesi, Eğitim Bilimleri Enstitüsü, İstanbul.

Keskin, Y., \& Yaman, E. (2014). A new paradigm in the primary school social studies curriculum and course books: Multicultural education. Turkish Studies, 9(2), 933-960. https://doi.org/10.7827/TurkishStudies.6438

Kızılçelik, S. (2003). Globalization and social sciences, (Genişletilmiş 2. Baskı). Ankara, Turkey: Anı Yayıncılık.

Özensel, E. (2013). Search for living together in Turkey and eastern societies: Multiculturalism or a new model. Journal of Academic Inquiries, 8(3), 1-17.

Öztürk, C. (1999). Teacher training in the Republican period, within Education in 75 Years (p. 283-310). Tarih Vakf1 Yayınları: İstanbul.

Öztürk, C. (2006). Social studies: an interdisciplinary outlook on social life. C. Öztürk (Ed.). Life Sciences and Social Studies Teaching within a Constructivist Approach (p. 21-50). Ankara: Pegem A Yayınc1lik.

Öztürk, C., \& Deveci, H. (2011). Evaluation of social studies curricula of different countries. C. Öztürk (Ed.) In the Social Studies Curricula of Different Countries (p. 1-41). Ankara: Pegem Akademi.

Patton, M. Q. (2014). Qualitative research and evaluation methods (Çev. M. Bütün). Ankara, Turkey: Pegem Akademi.

Polat, İ., \& Kılıç, E. (2013). Multicultural education in Turkey and teachers' competencies in multicultural education. YYU Journal of Education Faculty, 10(1), 352-372.

Polat, S. (2009). Personality traits of pre-service teachers towards multicultural education. International Online Journal of Educational Sciences, 1(1), 154-164.

Safran, M. (2008). An overview of social studies teaching. In Social Studies Teaching with Special Training Methods (p. 2-21). Ankara: Pegem Akademi.

Santrock, J. W. (2001). Educational psychology. New York: McGraw Hill.

Şimşek, A. (2007). "Global links" in social studies lessons in Turkey: a comparative study with certain world countries. M. Safran, D. Dilek (Ed.) In Identity, Citizenship and History Education in the 21st Century (p. 345-364). İstanbul: Yeni İnsan Yayınevi.

Timur, F. (2001). Multiculturalism: Is it an Alternative to Modern Nation-States Project?, Türkiye ve Siyaset Dergisi.

Toulmin, S. (1999). The ambiguities of globalization. Futures, 31(9-10), 905-912. https://doi.org/10.1016/S0016-3287(99)00049-X

Üstel, F. (2011). Citizenship training from the $2^{\text {nd }}$ Constitutionalism to today in the pursuit of a good citizen. 5. Bask1. İstanbul: İletişim Yayınları.

Ware, F. (2006). Culturally responsive teaching that supports a culture of achievement for African American students. Urban Education, 41(4), 427-456. https://doi.org/10.1177/0042085906289710

Welton, D. A., \& Mallon, J. T. (1999). Children and their world. New York: Houghton Mifflin Company.

Yazıcı, S., Başol, G., \& Toprak, G. (2009). Multicultural education attitudes of teachers: A reliability and validity study. Hacettepe Üniversitesi Ĕ̈itim Fakültesi Dergisi, 37, 229-242.

Yıldırım, A., \& Şimşek, H. (2011). Qualitative Research in Social Sciences. 8. Baskı. Ankara: Seçkin Yayıncılık

Yıldırım, H. (2002). Turkish Revolution Searching for Its Identity. Downloaded from http://www.historicalsense.com/Archive/Turk_kim_3.htm on January 15, 2005

Yılmaz, K., \& Horzum, M. B. (2005). Globalization, information technologies and university. İnönü Üniversitesi Ĕgitim Fakültesi Dergisi, 6(10), 103-121.

YÖK (1998). Faculty of Education, Teacher Training Undergraduate Programs, Ankara.

\section{Copyrights}

Copyright for this article is retained by the author(s), with first publication rights granted to the journal.

This is an open-access article distributed under the terms and conditions of the Creative Commons Attribution license which permits unrestricted use, distribution, and reproduction in any medium, provided the original work is properly cited. 